\title{
Status of Capybaras (Hydrochoerus hydrochaeris Rodentia: Hydrochaeridae) and Potential for Establishment in Florida ${ }^{1}$
}

\author{
Brandon Parker, C. Jane Anderson, Christina Romagosa, Samantha Wisely, Daniel Pearson, \\ John Seyjagat, and Katherine Ashley Sayler ${ }^{2}$
}

\section{Introduction}

Capybaras are the world's largest rodents. They are typically 2 feet tall, with an average body length of 4 feet and a weight of $100 \mathrm{lbs}$ (Mones and Ojasti 1986). These semiaquatic herbivores are native to South America (Figure 1) but have been spotted in the state of Florida, which has raised concerns of their potential to establish populations in the state.

A capybara sighting was first reported in Florida in 1992 as roadkill south of the Santa Fe River, east of La Crosse (Alachua County). Since then, at least 35 observations of capybaras in Florida have been reported to EDDMapS, a web-based mapping system developed by the University of Georgia for documenting invasive species (EDDMapS 2017). These reports have spanned 13 counties, as far west as Gulf County and extending as far south as Collier County (Figure 2). Most observations have been in north-central Florida, with most of the reports from Alachua County (EDDMapS 2017). An unintentional release in north-central Florida in 1994 may be the source for the capybaras sighted, but that is speculative: as yet no definitive source has been identified (USGS 2017; J. Seyjagat unpublished).

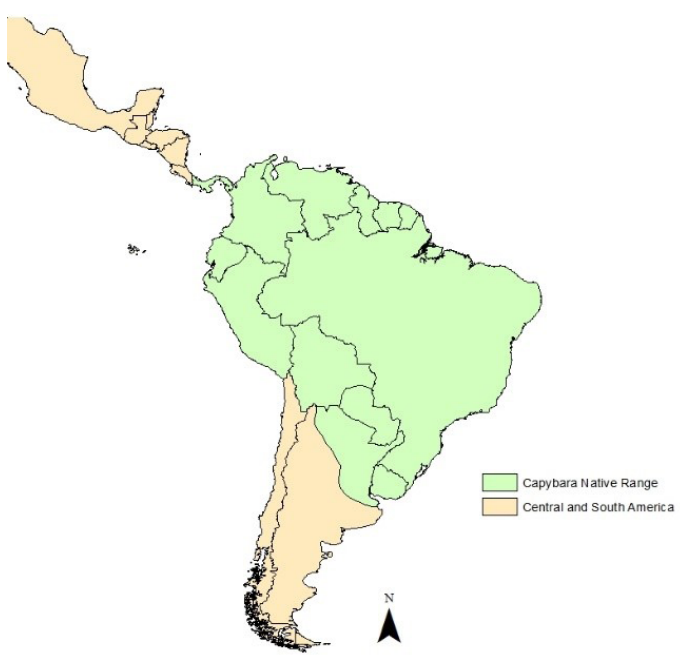

Figure 1. Capybaras native range.

Credits: Jane Anderson, UF/IFAS. Based on IUCN Red List, 2017

1. This document is WEC393, one of a series of the Wildlife Ecology and Conservation Department, UF/IFAS Extension. Original publication date December 2017. Visit the EDIS website at http://edis.ifas.ufl.edu.

2. Brandon Parker, laboratory technician, Department of Wildlife Ecology \& Conservation; C. Jane Anderson, post doctoral associate, Department of Wildlife Ecology \& Conservation; Christina Romagosa, assistant research professor, Department of Wildlife Ecology \& Conservation; Samantha Wisely, associate professor, Department of Wildlife Ecology \& Conservation; Daniel Pearson, environmental specialist, Florida Park Service; John Seyjagat, executive director, Zoological Association of America; and Katherine Ashley Sayler, research assistant professor, Department of Wildlife Ecology \& Conservation; UF/IFAS Extension, Gainesville, FL 32611.

The Institute of Food and Agricultural Sciences (IFAS) is an Equal Opportunity Institution authorized to provide research, educational information and other services

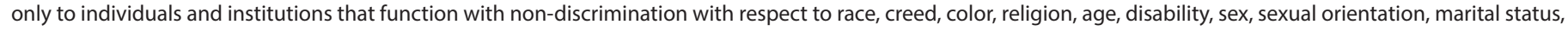

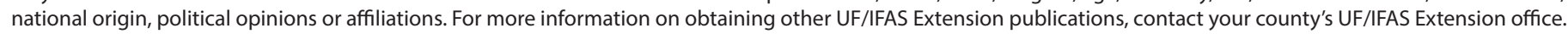
U.S. Department of Agriculture, UF/IFAS Extension Service, University of Florida, IFAS, Florida A \& M University Cooperative Extension Program, and Boards of County Commissioners Cooperating. Nick T. Place, dean for UF/IFAS Extension. 


\section{How did they get here?}

In 1994, eight capybaras were unintentionally released from the Lubee Foundation in Alachua County, Florida (J. Seyjagat unpublished). Damage to a pasture fence from a storm allowed these animals to escape. By 1995, all original escapees were recovered, but they had already started reproducing in northern Alachua County between La Crosse and Monteocha. Between 1994 and 2003, thirtyeight additional capybaras were removed from this area (J. Seyjagat unpublished). It is possible that this release is what led to the capybaras found around the Santa Fe River and O'Leno State Park (J. Seyjagat unpublished). Capybaras were also cited near Gainesville during this period (EDDMapS 2017).

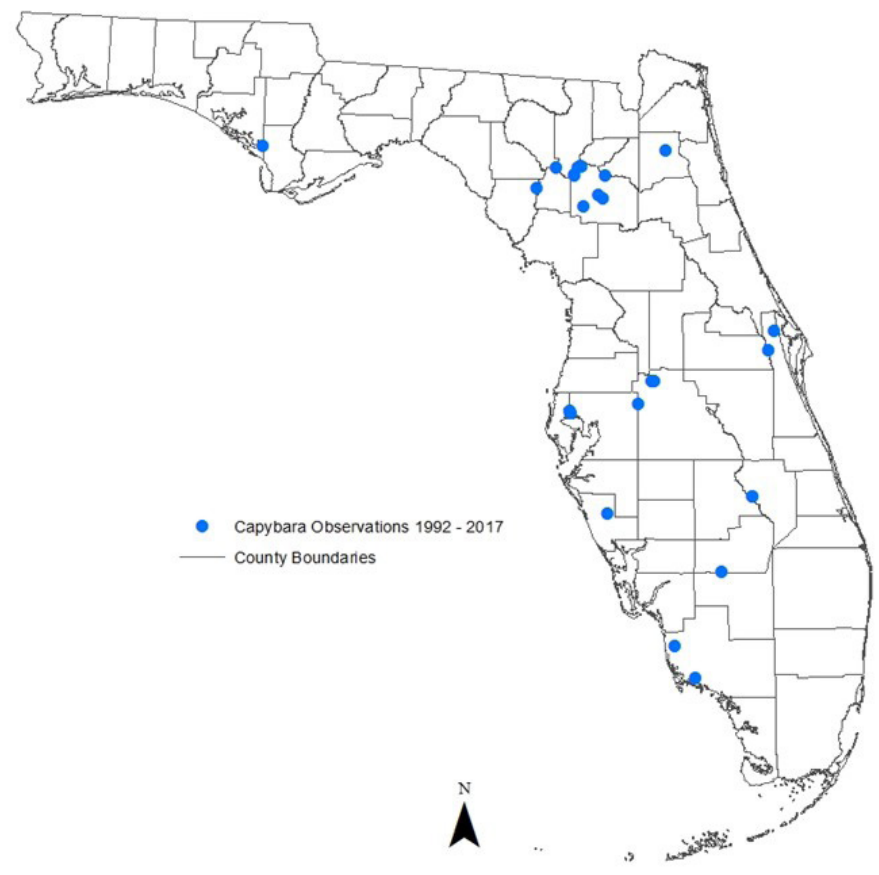

Figure 2. Sighting of capybara in Florida. Blue dots indicate observation sites.

Credits: Jane Anderson, UF/IFAS. Based on EDDMapS.org

\section{Where are capybaras in Florida?}

Little is known about the present population status or distribution of capybaras in Florida. Currently the species is classified as an "observed species" by the Florida Fish and Wildlife Conservation Committee (FWC) because no established population has been definitively confirmed (FWC 2017a). The total number of non-captive capybaras (meaning those neither kept as pets nor in a zoo) in Florida is unknown. There may be an established population in north-central Florida near the Santa Fe River (USGS 2017), as sightings have been reported since the unintentional release of capybaras in 1994. Because capybaras have an average lifespan of six to eight years in the wild (Nowak 1999), consistent sightings since 1994 and observations of juveniles (EDDMapS 2017) suggest there is a breeding population.

A pair of capybaras lived around Alligator Lake, Lake City, Florida, from approximately 2001 to 2015 (C. Pittman, pers. comm.). This observation provided evidence that long-term survival of capybaras in Florida is possible.

\section{Capybara Ecology and Natural History \\ Morphology}

Capybaras have large, barrel-shaped bodies and are covered in coarse hair that ranges in color from dark reddish to light brown (Figure 3). They have a stubby tail and short limbs. They have four digits on the forefeet and three on the hindfeet. Males have a nasal gland on their head, which they use to find and identify other capybaras through scent. Observers of capybaras can use presence of nasal glands to distinguish between sexes (Azara 1802).

Capybaras are adapted to live in and around water. The digits on their toes are webbed, which helps the capybaras swim through the water. The head is also adapted for swimming: ears, eyes, and nostrils are placed high on the broad head to keep them above the water line.

\section{Habitat Requirements}

Capybaras are capable of living in a wide variety of habitats that have a permanent body of water (Mones and Ojasti 1986). These habitat types in Florida include forested riverbanks, wetlands, and mangrove swamps. Proximity to water is essential to capybaras because they use water for mating, drinking, protection from predators, thermoregulation, and grazing on aquatic plants (Campos-Krauer et al. 2014). Capybaras are selective eaters, with a diet consisting of specific aquatic plants and grasses. Only during the dry season when food is less abundant will they eat a wider range of vegetation (Desbiez et al. 2011). In addition to water, they require grazing grounds and a forested area to protect them from predators and the sun. Capybaras also flourish in agricultural areas, where they commonly feed on crops and graze with cattle in pastures (Felix et. al 2014). In Paraguay, conversion of forest into pastureland has allowed capybaras to expand beyond their native range (CamposKrauer and Wisely 2011). 


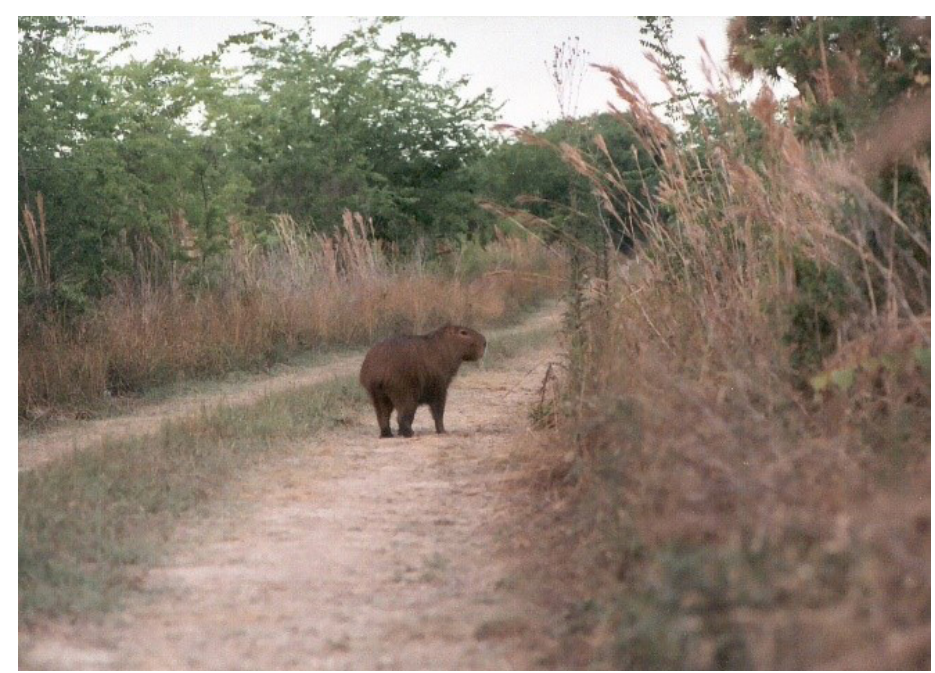

Figure 3. A capybara spotted at Paynes Prairie, Florida (approximately 2003).

Credis: Daniel Pearson, Florida Department of Environmental Protection

\section{Social Structure}

Capybaras are social animals and live in herds that usually include 5-14 animals. This number varies seasonally, with smaller group sizes during the wet season compared to the dry season (Mones and Ojasti 1986). Capybara groups consist of a few adult females and their offspring, a dominant adult male, and, occasionally, one or two submissive males. However, the dominant male will often expel other males from the group, so adult males often live alone or in pairs or trios outside of herds.

\section{Potential Impacts of Non-Native Capybaras}

Non-native species are those that have been introduced to an area in which they do not naturally occur. These introductions are sometimes innocuous. Species are considered invasive after they have been introduced to a new area and if they threaten human health or cause damage to native ecosystems, plants, or wildlife, or economic resources (FWC 2017c).

In order to keep capybaras in captivity in Florida, a Class III wildlife permit is required. (FWC 2017b). This is the lowest level the Florida Fish and Wildlife Conservation Commission uses to categorize captive animals-many species in this category are common pets. For example, other Class III species include rats, parrots, guinea pigs, and foxes. It is possible that many sightings of capybaras throughout Florida are escaped or abandoned pets.

To date, no negative environmental or human impacts have been documented from introduced capybaras in Florida.
However, the possible impacts this species could have on the environment, economy, and human health are largely unexplored. Data from the capybara's native range can give clues as to the impacts that could potentially be experienced in Florida, should a capybara population establish and expand.

Capybaras act as reservoirs, or carriers, for pathogens that can infect humans or domesticated animals. One of the risks of these animals establishing in Florida is their potential to introduce new pathogens, or to increase the prevalence of an already-existing pathogen. One such disease-causing agent is Rickettsia rickettsii, the bacterium that causes Rocky Mountain spotted fever in both North and South America. Capybaras are a reservoir for this bacterium, which is zoonotic (capable of being transmitted from animals to people). This is notable because Rocky Mountain spotted fever can be a fatal human disease (Dantas-Torres 2007). In Brazil, it is thought that the recent increase of Brazilian spotted fever (the region's name for Rocky Mountain spotted fever) may be due to increases in the abundance of capybaras (Labruna 2013). An infected tick can pass Rickettsia rickettsii to a capybara while feeding. Ticks that subsequently feed on that capybara can become infected by the bacterium, and then spread it to other species, including humans, through a tick bite. Capybaras are usually asymptomatic carriers of Rickettsia, meaning they show no signs of infection, making it very challenging to know when they are carrying the disease agent (Cueto 2013).

Another harmful organism that capybaras can carry is Trypanosoma evansi. Trypanosomes are flagellate protozoans (single-celled organisms, like those that can cause diseases such as sleeping sickness or Chagas disease). T. evansi can infect a wide range of wild and domesticated hosts, but horses are particularly susceptible (Gutierrez et al. 2010). Surra (a disease caused by T. evansi found in camels, horses, and dogs) causes nonspecific clinical signs making it difficult to diagnose (Desquesnes et al. 2013). This, coupled with its high mortality rate if left untreated, makes it a dangerous disease to horses in particular (Desquesnes et al. 2013). T. evansi has not been reported in North America, but capybaras may increase the risk of establishment of the organism if it were accidentally introduced.

In addition to the possibility of harboring disease-causing microorganisms, capybaras also can negatively impact agricultural operations in their native range. Capybaras are regarded as pests by many in South America because they damage crops, especially where their populations are large. They eat rice, sugarcane, corn, and soybeans, with the most 
damage inflicted on corn (Felix et al. 2014). According to the USDA, Florida produced 827,400 tons of corn and $16,904,000$ tons of sugarcane in 2016 (USDA 2017). If capybara populations became established in Florida, they have the potential to harm these industries. Also, due to their flexible plantbased diet, it is not known if capybaras would feed on other crops found in Florida such as peanuts, strawberries, or other low-growing vegetables or fruit crops.

\section{Management}

At their current population levels, it does not appear capybaras are having an economic impact or detrimental effects on the natural environment in Florida. Although non-native species are typically removed whenever possible from conservation lands, other more invasive and damaging species, such as feral hogs, are higher priorities for active management. Additional work is needed to determine if reported sightings are locations of established herds and to estimate population sizes of capybaras in the state. Research on capybara behavior, potential for population establishment and expansion, potential threats to human health, and environmental impacts in Florida also should be pursued.

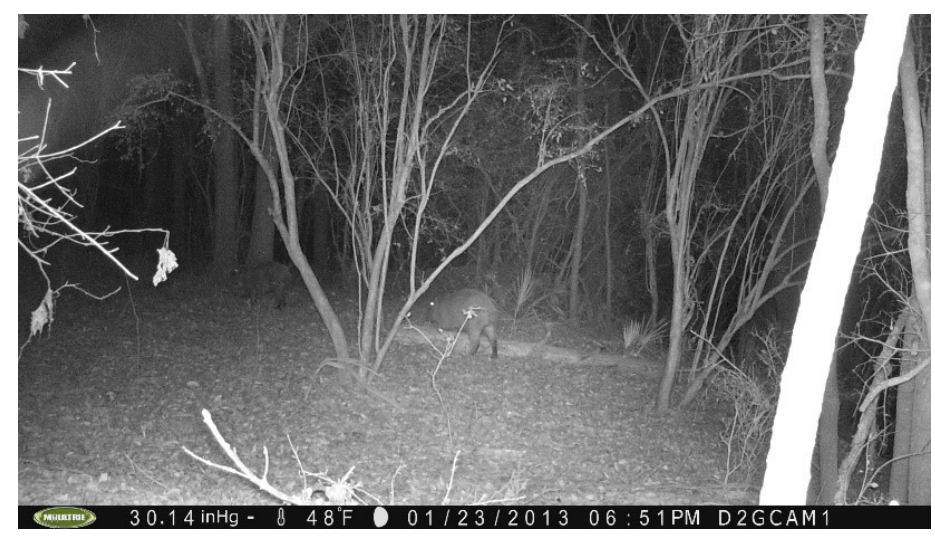

Figure 4. Two capybaras caught on a camera trap in Florida on January 23, 2013.

Credits: Daniel Pearson, Florida Department of Environmental Protection

\section{Resources}

To see a list of reported sightings, go to

https://EDDMapS.org/distribution/viewmap. cfm? sub=10381.

To report a sighting of capybara you can call Florida Fish and Wildlife Conservation Commission at 1-888-Ive-Got1 (1-888-483-4681) or visit http://IveGot1.org.

\section{References}

Alho, C. J., and N. L. Rondon. 1987. "Habitats, population densities, and social structure of capybaras (Hydrochaeris hydrochaeris, Rodentia) in the Pantanal, Brazil." Revista Brasilerira de Zoologia. 4(2): 139-149. doi:10.1590/ S0101-81751987000200006

Azara, F. 1802. Apuntamientos para la historia natural de los quadrúpedos del Paraguay y río de la Plata. Madrid: Imprenta de la Viuda de Ibarra.

Benson, A. 2017. Hydrochoerus hydrochaeris (Linnaeus, 1766). Retrieved on August 23, 2017 from https://nas. er.usgs.gov/queries/FactSheet.aspx? speciesID=2587.

Campos-Krauer, J. M., and S.M. Wisely. 2011.

"Deforestation and cattle ranching drive rapid range expansion of capybara in the Gran Chaco ecosystem." Global Change Biology. 17(1): 206-218. doi:10.1111/j.1365-2486.2010.02193.x

Campos-Krauer, J. M., S. M. Wisely, I. K. Benitez, K. Robles, and R. T. Golightly. 2014. "Home range and habitat use of capybara in newly invaded pastureland in the dry Chaco region of Paraguay." Therya. 5(1): 61-79. doi:10.12933/ therya-14-177

Cueto, G. R. 2013. "Diseases of Capybara." In Moreira, J. R., Ferraz, K. M., Herrera, E. A., and D. W. Macdonald (Eds.), Capybara: biology, use and conservation of an exceptional neotropical species (pp. 169-177). New York, NY: Springer Science \& Business Media. Retrieved July 18, 2017, from https://link.springer.com/content/pdf/10.1007\% 2F978-1-4614-4000-0_9.pdf.

Dantes-Torres, F. 2007. "Rocky Mountain spotted fever." Lancet Infectious Diseases. 7(11): 724-732. doi:10.1016/ S1473-3099(07)70261-X

Desquesnes, M., P. Holzmulle, D. Lai, A. Dargantes, Z. Lun, and S. Jittaplapong. 2013. "Trypanosoma evansi and surra: A review and perspectives on origin, history, distribution, taxonomy, morphology, hosts, and pathogenic effects." BioMedical Research International. 2013: 1-22. doi:10.1155/2013/194176

Desbiez, A. L. J., S. A. Santos, J. M. Alvarez, and W. M. Tomas. 2011. "Forage use in domestic cattle (Bos indicus), capybara (Hydrochoerus hydrochaeris) and pampas deer (Ozotoceros bezoarticus) in a seasonal neotropical wetland." Mammalian Biology 76(3): 351-357. doi:10.1016/j. mambio.2010.10.008 
Early Detection and Distribution Mapping System (EDDMapS). 2017. Capybara Hydrochoerus hydrochaeris. Retrieved on August 16, 2017 from https:/EDDMapS.org/ distribution/viewmap.cfm?sub=10381.

Felix, G., I. Almeida, U. Piovezan, R. Garcia, K. Lima, I. Nääs, D. Salgado, M. Pilecco, and M. Belloni. 2014. "Feeding behavior and crop damage caused by capybaras (Hydrochoerus hydrochaeris) in an agricultural landscape." Brazilian Journal of Biology. 74(4): 779-786. doi:10.1590/1519-6984.02113

Ferraz, K., M. Lechevalier, H. Couto, and L. Verdade. 2003. "Damage caused by capybaras in a corn field." Scientia Agricola. 60(1): 191-194. doi:10.1590/

S0103-90162003000100029

Florida Fish and Wildlife Conservation Commission. 2017a. Nonnative Mammals. Retrieved on August 22, 2017 from http://myfwc.com/wildlifehabitats/nonnatives/ mammals/.

Florida Fish and Wildlife Conservation Commission. 2017b. Captive Wildlife Licenses \& Permits. Retrieved on August 22, 2017 from http://myfwc.com/license/ captive-wildlife/.

Florida Fish and Wildlife Conservation Commission. 2017c. Florida's Exotic Fish and Wildlife. Retrieved on November 26, 2017 from http://myfwc.com/wildlifehabitats/ nonnatives/.

Gutierrez, C., M. Desquesnes, L. Touratier, and P. Büscher. 2010. "Trypanosoma evansi: Recent outbreaks in Europe." Veterinary Parasitology. 174(1): 26-29. doi:10.1016/j. vetpar.2010.08.012

Labruna, M. 2013. In Moreira, J. R., K. M. Ferraz, E. A. Herrera, and D. W. Macdonald (Eds.), "Brazilian spotted fever: The role of capybara." Capybara: biology, use and conservation of an exceptional neotropical species (pp 371-383). New York, NY: Springer Science \& Business Media. Retrieved July 18, 2017, from https://link.springer. cottim/content/pdf/10.1007\%2F978-1-4614-4000-0_23.pdf.

Mones, A., and J. Ojasti. 1986. "Hydrochaeris hydrochaeris." Mammalian Species. 264: 1-7. Retrieved December 13, 2017, from https://academic.oup.com/mspecies/articleabstract/doi/10.2307/3503784/2600593?redirectedFrom=full text
Nowak, R. 1999. Walker's Mammals of the World (Vol. 2, 6th ed., pp. 1673). Baltimore, MD:Johns Hopkins University.

United States Department of Agriculture. 2017. 2016 Florida Agriculture Overview. Retrieved on August 1, 2017 from https://www.nass.usda.gov/Quick_Stats/Ag_Overview/stateOverview.php?state=FLORIDA. 